\title{
Organic pest management of major insect pests of Ashwagandha, Withania somnifera Dunal
}

\author{
RK Murali Baskaran*, K Suresh, B Usha Rani and P Parthiban \\ Department of Agricultural Entomology, Agricultural College and Research Institute, Tamil Nadu Agricultural University, \\ Madurai 625 104, Tamil Nadu, India. \\ *Corresponding author. Email: rcrkm2013@gmail.com
}

Copyright (C) 2016 Baskaran et al. This article remains permanently open access under the terms of the Creative Commons Attribution License 4.0, which permits unrestricted use, distribution, and reproduction in any medium, provided the original work is properly cited.

Received 20th May, 2016; Accepted 14th June, 2016

ABSTRACT: An organic based bio-intensive module was developed and evaluated under field condition at the Department of Agricultural Entomology, Agricultural College and Research Institute, Madurai for the management of major insect pests of ashwagandha (Withania somnifera Dunal) during August 2012 to March 2013 with the weather condition of $28 \pm 1.4^{\circ} \mathrm{C}$ and $73 \%$ relative humidity $(\mathrm{RH})$. A Bio-intensive module consisting of various components like vermicompost 2 t/ha + neem or karanj cake $250 \mathrm{~kg} / \mathrm{ha}+$ bio-fertilizers $(2 \mathrm{~kg} / \mathrm{ha})+\mathrm{NPK}(45: 50: 50 \mathrm{~kg} / \mathrm{ha})+$ Trichogramma chilonis 125000 parasitoids/ha (3 releases on 15, 45, 75 DAP) + neem gold $1.5 \mathrm{ml} /$ lit (3 sprays on 20, 50, $80 \mathrm{DAP})+$ fish oil rosin soap $25 \mathrm{~g} /$ litre (5 sprays on 30,60, 90, 120, $150 \mathrm{DAP}$ ) imposed on ashwagandha field was found to be effective in reducing the incidence of major pests of ashwagandha, recording the mean leaf damage of 4.4 per cent with a reduction over full dose of NPK of 78.0 per cent for Epilachna beetle (Henosepilachna vigintioctopunctata Fab.) and mean population of 2.6 nos./leaf with a reduction over full dose of NPK of 72.9 per cent for mealybugs [Coccidohystrix insolitus (Green)]. Module I has recorded the highest yield of $547.2 \mathrm{~kg}$ dried roots/ha, in contrast to full dose of NPK (344.8 $\mathrm{kg}$ dried roots $/ \mathrm{ha})$ and untreated check (275.6 kg dried roots $/ \mathrm{ha})$.

Key words: Bio-intensive module, Withania somnifera, Henosepilachna vigintioctopunctata, Coccidohystrix insolitus, management.

\section{INTRODUCTION}

Ashwagandha is one of the potential medicinal crops. The dried roots are rich source of withanine and somniferine which are mainly used in ayurvedic and unani preparations (Ravikumar et al., 2007). Eleven species of phytophagous pests including Henosepilachna vigintioctopunctata Fab., Myllocerus discolor Fab. and Myllocerus viridanus Fab., Deilephila nerii Linn., Leaf miner, Oxyra chistarandus Fab., Ferrisia virgata, Nezara virudula, Aphids, Tetranychus urticae Koch. and Helicoverpa sp. have been noticed to be associated with ashwagandha (Murali Baskaran et al., 2007; Sharma et al., 2014). Two types of epilachna beetles commonly found in India are E. vigintioctopunctata and $E$. dodecastigma and adult scrapes the green matter of the upper and lower sides of the leaves of ashwagandha leaving behind only a network of veins. This characteristic scraping makes the leaves papery and the infested egg plants exhibited inter-venal damage or holes on the leaves. In the grub infested leaves, fully damaged epidermis, parenchyma cells and phloem cells of vascular bundles are observed (Kamrul Islam et al., 2011, Mohanchander et al., 2013).

C. insolitus is a polyphagous and adult female has very little dorsal wax and secretes a white, waxy ovisac up to 6 times as long as the body of the female, which is more typical of some Coccidae. The immature stages do not secrete a thick layer of mealy wax, the body being shiny yellow-green with sub-median grey spots on two abdominal and one thoracic segment (Moore et al., 2014). Since ashwagandha has a lot of medicinal properties, chemical insecticides cannot be employed to manage the insect pests. At the same time, works on eco-friendly methods are in infancy in ashwagandha pest management. Hence, the present attempts were made to develop and evaluate a bio-intensive module against the key pests of ashwagandha. 
Table 1. Percent leaf damage by epilachna beetle on ashwagandha, as influenced by bio-intensive module.

\begin{tabular}{|c|c|c|c|c|c|c|c|}
\hline \multirow[b]{2}{*}{ Treatment } & \multicolumn{5}{|c|}{ \% leaf damage by Epilachna beetle at monthly interval } & \multirow[b]{2}{*}{ Mean } & \multirow[b]{2}{*}{$\begin{array}{c}\% \text { reduction } \\
\text { over NPK }\end{array}$} \\
\hline & $\begin{array}{c}30 \\
\text { DAP }\end{array}$ & $\begin{array}{c}60 \\
\text { DAP }\end{array}$ & $\begin{array}{c}90 \\
\text { DAP }\end{array}$ & $\begin{array}{l}120 \\
\text { DAP }\end{array}$ & $\begin{array}{r}150 \\
\text { DAP }\end{array}$ & & \\
\hline Module I & $\begin{array}{c}2.6 \\
(6.81)^{\mathrm{a}}\end{array}$ & $\begin{array}{c}3.4 \\
(10.62)^{\mathrm{a}}\end{array}$ & $\begin{array}{c}4.2 \\
(11.79)^{\mathrm{a}}\end{array}$ & $\begin{array}{c}5.6 \\
(13.69)^{\mathrm{a}}\end{array}$ & $\begin{array}{c}6.2 \\
(14.42)^{\mathrm{a}}\end{array}$ & 4.4 & 78.0 \\
\hline Module II & $\begin{array}{c}4.2 \\
(11.81)^{\mathrm{b}}\end{array}$ & $\begin{array}{c}5.8 \\
(13.92)^{\mathbf{b}}\end{array}$ & $\begin{array}{c}6.4 \\
(14.65)^{b}\end{array}$ & $\begin{array}{c}7.2 \\
(15.51)^{\mathrm{b}}\end{array}$ & $\begin{array}{c}8.5 \\
(16.95)^{b}\end{array}$ & 6.4 & 68.0 \\
\hline NPK (90:50:50 kg/ha) & $\begin{array}{c}11.8 \\
(20.09)^{d}\end{array}$ & $\begin{array}{c}15.2 \\
(22.95)^{d}\end{array}$ & $\begin{array}{c}20.4 \\
(26.85)^{d}\end{array}$ & $\begin{array}{c}24.3 \\
(29.50)^{d}\end{array}$ & $\begin{array}{c}28.5 \\
(32.26)^{d}\end{array}$ & 20.0 & -- \\
\hline Untreated check & $\begin{array}{c}10.3 \\
(18.72)^{\mathrm{c}}\end{array}$ & $\begin{array}{c}13.5 \\
(21.56)^{\mathrm{c}}\end{array}$ & $\begin{array}{c}18.2 \\
(25.25)^{\mathrm{c}}\end{array}$ & $\begin{array}{c}21.2 \\
(27.52)^{\mathrm{c}}\end{array}$ & $\begin{array}{c}24.3 \\
(29.54)^{\mathrm{c}}\end{array}$ & 17.5 & -- \\
\hline $\begin{array}{l}\text { SEd } \\
\text { CD 5\% }\end{array}$ & $\begin{array}{l}0.39 \\
0.90\end{array}$ & $\begin{array}{l}0.29 \\
0.65\end{array}$ & $\begin{array}{l}0.12 \\
0.27\end{array}$ & $\begin{array}{l}0.17 \\
0.39\end{array}$ & $\begin{array}{l}0.16 \\
0.37\end{array}$ & - & - \\
\hline
\end{tabular}

$\mathbf{T}_{1}$ Module I, [vermicompost 2t/ha + neem $250 \mathrm{~kg} / \mathrm{ha}$ + bio-fertilizers $(2 \mathrm{~kg} / \mathrm{ha})+$ NPK $(45: 50: 50 \mathrm{~kg} / \mathrm{ha})+$ Trichogramma chilonis 125000 parasitoids/ha ( 3 releases on 15, 45, $75 \mathrm{DAP})+$ neem gold $1.5 \mathrm{ml} / \mathrm{lit}$ ( 3 sprays on 20,50, $80 \mathrm{DAP})+$ fish oil rosin soap $25 \mathrm{~g} / \mathrm{litre}(5 \mathrm{sprays}$ on $30,60,90,120,150$ DAP)]. $\mathbf{T}_{2}$ Module II, [vermicompost 2t/ha + karanj cake $250 \mathrm{~kg} / \mathrm{ha}+$ bio-fertilizers $(2 \mathrm{~kg} / \mathrm{ha})+\mathrm{NPK}(45: 50: 50 \mathrm{~kg} / \mathrm{ha})+$ Trichogramma chilonis 125000 parasitoids/ha (3 releases on 15, 45, $75 \mathrm{DAP})+$ neem gold $1.5 \mathrm{ml} / \mathrm{lit}$ (3 sprays on 20, 50, $80 \mathrm{DAP})+$ fish oil rosin soap $25 \mathrm{~g} / \mathrm{litre}$ ( $5 \mathrm{sprays}$ on 30 , 60 , 90, 120, 150 DAP)]. Figures in parentheses are arcsine transformed values; DAP, days after planting. In a column, means followed by same letter(s) are not significantly different by DMRT $(P=0.05)$.

\section{MATERIALS AND METHODS}

A field experiment was conducted at Agricultural College and Research Institute, Madurai (latitude: $9^{0} 54$ " N; longitude: $78.54^{\circ} \mathrm{E}$; altitude: $147 \mathrm{msl}$ ) during August 2012 to March $2013\left(28 \pm 1.4^{\circ} \mathrm{C}\right.$ and $\left.73 \% \mathrm{RH}\right)$ with the following treatments.

$\mathrm{T}_{1}$ Module I: [vermicompost 2t/ha + neem $250 \mathrm{~kg} / \mathrm{ha}+$ bio-fertilizers (2 kg/ha) + NPK (45:50:50 kg/ha) + Trichogramma chilonis 125000 parasitoids/ha (3 releases on $15,45,75 \mathrm{DAP}$ ) + neem gold $1.5 \mathrm{ml} / \mathrm{lit}$ ( 3 sprays on $20,50,80 \mathrm{DAP}$ ) + fish oil rosin soap $25 \mathrm{~g} /$ litre (5 sprays on $30,60,90,120,150 \mathrm{DAP})]$

$\mathrm{T}_{2}$ Module II: [vermicompost $2 \mathrm{t} / \mathrm{ha}+$ karanj cake 250 $\mathrm{kg} / \mathrm{ha}+$ bio-fertilizers $(2 \mathrm{~kg} / \mathrm{ha})+$ NPK $(45: 50: 50 \mathrm{~kg} / \mathrm{ha})+$ Trichogramma chilonis 125000 parasitoids/ha (3 releases on $15,45,75 \mathrm{DAP}$ ) + neem gold $1.5 \mathrm{ml} / \mathrm{lit}$ ( 3 sprays on $20,50,80 \mathrm{DAP}$ ) + fish oil rosin soap $25 \mathrm{~g} /$ litre (5 sprays on $30,60,90,120,150 \mathrm{DAP})]$

$T_{3}$ NPK (90:50:50 kg/ha).

$\mathrm{T}_{4}$ Untreated check.

Ashwagandha seedlings were planted in ridges and furrows with a spacing of $60 \times 30 \mathrm{~cm}$. Each plot measuring $4 \times 5 \mathrm{~m}$ was replicated five times for each treatment and compared with full dose of NPK and untreated check. All treatments involving organic sources of nutrients were included with half a dose of $\mathrm{N}$ and full dose of $\mathrm{P}$ and $\mathrm{K}$. Vermicompost $2 \mathrm{t} / \mathrm{ha}$, bio-fertilizers each $2 \mathrm{~kg} / \mathrm{ha}$, NPK (45:50:50 kg/ha) and two oil cakes, neem and karanj at $250 \mathrm{~kg} / \mathrm{ha}$ were applied basally during main field preparation. Percent leaflet damage by hadda beetle and population of mealybug/leaf were observed at monthly interval starting from 30 days to 150 days after planting. Field experiment was conducted in a Randomized Block Design (RBD). Data on percent leaflet damage and population of mealybug and yield were analysed statistically after subjecting them in to arcsine and square root transformation, respectively. Means were separated by DMRT.

\section{RESULTS}

Bio-intensive module I [vermicompost 2t/ha + neem 250 $\mathrm{kg} / \mathrm{ha}+$ bio-fertilizers $(2 \mathrm{~kg} / \mathrm{ha})+\mathrm{NPK}(45: 50: 50 \mathrm{~kg} / \mathrm{ha})+$ Trichogramma chilonis 125000 parasitoids/ha (3 releases on $15,45,75 \mathrm{DAP})+$ neem gold $1.5 \mathrm{ml} / \mathrm{lit}$ (3 sprays on $20,50,80 \mathrm{DAP}$ ) + fish oil rosin soap $25 \mathrm{~g} /$ /itre (5 sprays on $30,60,90,120,150 \mathrm{DAP})]$ was effective in reducing the incidence of $E$. vigintioctopunctata on ashwagandha, recording the overall mean leaf damage of 4.4 percent with a reduction over full dose of NPK of 78.0 percent, followed by bio-intensive module II [vermicompost 2t/ha + karanj cake $250 \mathrm{~kg} / \mathrm{ha}$ + bio-fertilizers $(2 \mathrm{~kg} / \mathrm{ha})+\mathrm{NPK}$ $(45: 50: 50 \mathrm{~kg} / \mathrm{ha})+$ Trichogramma chilonis 125000 parasitoids/ha (3 releases on 15, 45, $75 \mathrm{DAP})+$ neem gold $1.5 \mathrm{ml} /$ lit (3 sprays on 20,50, $80 \mathrm{DAP}$ ) + fish oil rosin soap $25 \mathrm{~g} /$ litre (5 sprays on 30,60, 90, 120, $150 \mathrm{DAP}$ )] $(6.4 \%$ leaf damage and $68.0 \%$ reduction over full dose of NPK), full dose of NPK $(20.0 \%)$ and untreated check $(17.5 \%)$ (Table 1). Module I recorded the lowest leaf damage of 2.6, 3.4, 4.2, 5.6 and 6.2 percent during 30 , $60,90,120$ and 150 days after planting, respectively 
Table 2. Percent leaf damage by mealybug on ashwagandha, as influenced by bio-intensive module

\begin{tabular}{|c|c|c|c|c|c|c|c|}
\hline \multirow[b]{2}{*}{ Treatment } & \multicolumn{5}{|c|}{ Number of mealybugs/leaf at monthly interval } & \multirow[b]{2}{*}{ Mean } & \multirow[b]{2}{*}{$\begin{array}{c}\% \text { reduction } \\
\text { over NPK }\end{array}$} \\
\hline & $\begin{array}{c}30 \\
\text { DAP }\end{array}$ & $\begin{array}{c}60 \\
\text { DAP }\end{array}$ & $\begin{array}{c}90 \\
\text { DAP }\end{array}$ & $\begin{array}{l}120 \\
\text { DAP }\end{array}$ & $\begin{array}{l}150 \\
\text { DAP }\end{array}$ & & \\
\hline Module I & $\begin{array}{c}2.4 \\
(1.54)^{\mathrm{a}}\end{array}$ & $\begin{array}{c}2.9 \\
(1.70)^{\mathrm{a}}\end{array}$ & $\begin{array}{c}3.3 \\
(1.79)^{\mathbf{a}}\end{array}$ & $\begin{array}{c}2.5 \\
(1.58)^{\mathrm{a}}\end{array}$ & $\begin{array}{c}1.9 \\
(1.38)^{\mathrm{a}}\end{array}$ & 2.6 & 72.9 \\
\hline Module II & $\begin{array}{c}3.2 \\
(1.78)^{b}\end{array}$ & $\begin{array}{c}2.9 \\
(1.70)^{\mathbf{b}}\end{array}$ & $\begin{array}{c}3.5 \\
(1.86)^{\mathbf{b}}\end{array}$ & $\begin{array}{c}4.2 \\
(2.52)^{b}\end{array}$ & $\begin{array}{c}3.1 \\
(1.77)^{b}\end{array}$ & 3.4 & 64.6 \\
\hline NPK (90:50:50 kg/ha) & $\begin{array}{c}9.5 \\
(3.08)^{d}\end{array}$ & $\begin{array}{c}11.2 \\
(3.34)^{d}\end{array}$ & $\begin{array}{c}12.3 \\
(3.50)^{d}\end{array}$ & $\begin{array}{c}7.8 \\
(2.79)^{d}\end{array}$ & $\begin{array}{c}7.2 \\
(2.68)^{d}\end{array}$ & 9.6 & -- \\
\hline Untreated check & $\begin{array}{c}6.3 \\
(2.51)^{\mathrm{c}}\end{array}$ & $\begin{array}{c}8.4 \\
(2.88)^{\mathrm{c}}\end{array}$ & $\begin{array}{c}9.3 \\
(3.05)^{\mathrm{c}}\end{array}$ & $\begin{array}{c}5.2 \\
(2.27)^{\mathrm{c}}\end{array}$ & $\begin{array}{c}5.5 \\
(2.34)^{\mathrm{c}}\end{array}$ & 6.9 & -- \\
\hline $\begin{array}{l}\text { SEd } \\
\text { CD 5\% }\end{array}$ & $\begin{array}{l}0.08 \\
0.18\end{array}$ & $\begin{array}{l}0.05 \\
0.12\end{array}$ & $\begin{array}{l}0.07 \\
0.16\end{array}$ & $\begin{array}{l}0.08 \\
0.18\end{array}$ & $\begin{array}{l}0.06 \\
0.14\end{array}$ & -- & -- \\
\hline
\end{tabular}

$\mathbf{T}_{1}$ Module I, [vermicompost 2t/ha + neem $250 \mathrm{~kg} / \mathrm{ha}+$ bio-fertilizers $(2 \mathrm{~kg} / \mathrm{ha})+$ NPK $(45: 50: 50 \mathrm{~kg} / \mathrm{ha})+$ Trichogramma chilonis 125000 parasitoids/ha (3 releases on 15, 45, $75 \mathrm{DAP})+$ neem gold $1.5 \mathrm{ml} / \mathrm{lit}$ ( 3 sprays on 20, 50, $80 \mathrm{DAP})+$ fish oil rosin soap $25 \mathrm{~g} / \mathrm{litre}(5 \mathrm{sprays}$ on 30, 60, 90, 120, 150 DAP)]. T2 Module II, [vermicompost 2t/ha + karanj cake $250 \mathrm{~kg} / \mathrm{ha}+$ bio-fertilizers (2 kg/ha) + NPK (45:50:50 kg/ha) + Trichogramma chilonis 125000 parasitoids/ha (3 releases on 15, 45, 75 DAP) + neem gold $1.5 \mathrm{ml} /$ lit ( 3 sprays on 20,50, 80 DAP) + fish oil rosin soap $25 \mathrm{~g} /$ litre (5 sprays on 30, 60, 90, 120, $150 \mathrm{DAP})$ ]. Figures in parentheses are arcsine transformed values; DAP, days after planting. In a column, means followed by same letter(s) are not significantly different by DMRT $(P=0.05)$.

Table 3. Dried roots of ashwagandha, as influenced by bio-intensive modules

\begin{tabular}{lc}
\hline Treatment $^{\star}$ & Dried roots (kg/ha) \\
\hline Module I & $547.2(23.39)^{\mathbf{a}}$ \\
Module II & $524.8(22.93)^{\mathbf{b}}$ \\
NPK $(90: 50: 50 \mathrm{~kg} / \mathrm{ha})$ & $344.8(18.52)^{\mathbf{c}}$ \\
Untreated check & $275.6(16.61)^{\mathbf{d}}$ \\
SEd & 0.06 \\
CD 5\% & 0.13 \\
\hline
\end{tabular}

*Mean of five replications. In a column, figures followed by same letter(s) are square root transformed values. Figures given in table are subject to square root transformation during statistical analysis.

followed by module II $(4.2,5.8,6.4,7.2$ and $8.5 \%)$ while the leaf damage was $11.8,15.2,20.4,24.3$ and 28.5 percent in full dose of NPK and 10.3, 13.5, 18.2, 21.2 and 24.3 percent in untreated check.

The population of Coccidohystrix insolitus was recorded to be 2.6 nos./leaf with a reduction over full dose of NPK of 72.9 percent in bio-intensive module I, followed by module II (3.4 nos./leaf and $64.6 \%$ reduction) when compared to full dose of NPK (9.6 nos./leaf) and untreated check (6.9 nos./leaf \% shoot damage) (Table 2). Module I recorded the lowest population of mealybugs of $2.4,2.9,3.3,2.5$ and 1.9 nos./leaf during 30, 60, 90, 120 and 150 DAP, respectively, followed by module II (3.2, 2.9, 3.5, 4.2 and 3.1 nos./leaf) while the population was $9.5,11.2,12.3,7.8$ and 7.2 nos./leaf in full dose of NPK and 6.3, 8.4, 9.3, 5.2 and 5.5 nos./ leaf in untreated check.

Module I recorded the highest yield of $547.2 \mathrm{~kg}$ dried roots/ha, followed by module II (524.8 kg dried roots $/ \mathrm{ha})$ in contrast to full dose of NPK (344.8 kg dried roots $/ \mathrm{ha})$ and untreated check (275.6 kg dried roots/ha) (Table 3).

\section{DISCUSSION}

In the present study, the combination of neem cake with vermicompost, bio-fertilizers and half dose of $\mathrm{N}$ and full dose of $P$ and $K$ was effective in reducing the damage caused by epilachna beetle and mealybug. The combination of vermicompost with inorganic fertilizers was reported to be effective in reducing the incidence of groundnut leafminer (Rao et al., 2001) and sucking pests of cotton (Balakrishnan et al., 2007). Increase of soil microflora in module applied ashwagandha field might be responsible for enhancing the induced systemic resistance in plant system against insect pests, as suggested by Kale et al. (1991) who reported the high load of cellulolytic and lignolytic organisms in soil applied with vermicompost.

Various parts of neem like neem cake and Neem gold played vital role in the module to suppress the population of epilachna beetle and mealybug. The effect of neem cake as a soil amendments in suppressing the population of insects was well demonstrated in Leucinodes orbonalis Guen., on brinjal. This might be due to the presence of triterpenoids in neem cake which exhibited high antifeedant property. Enhancement of phenol and ash content in plant system, applied with organic sources of nutrients in soil has been demonstrated in several crops including brinjal (Suresh et al., 2007) and cotton (Balakrishnan et al., 2005). Phenols are often associated with feeding deterrence or growth inhibition. Neem in the 
form of oil, cake and neem seed kernel extract were reported to be effective against various stages of epilachna beetle (Diaz Napal et al., 2010; Venkatesh and David, 2003).

Five rounds of application of fish oil rosin soap (FORS) as one of the components in the present module was responsible to contain the mealybug. Fish oil rosin soap at 2.5 per cent was reported to be effective in managing several pests of Horticultural crops (Muthukrishnan et al., 2006; Murali Baskaran et al., 2009). However, it was reported that the FORS was effective to manage none of the pests of senna. FORS kills the pests by causing spiracle blockage, cellular disruption and cuticle desiccation (Ware, 1994).

\section{Conclusion}

With reference to the pests attacking ashwagandha, we are in the stage of inventerization of various pests. Though ashwagandha has insecticidal properties, it is being attacked and ravaged by several sucking and lepidopteran insects. Unless we protect the ashwagandha from pests complex, it could be used neither phyto-insecticides nor the sources for ayurvedic or unani medicine preparations. We are in infancy in developing eco-friendly pest management tactics for ashwagandha. Though array of natural enemies are available, they are only in record and further exploitation of them through suitable augmentation and conservation has become the mandate, for which ecology, biology, damage potential etc. of the pests of ashwagandha are to be studied and documented. Since the chemical control is helpless in ashwagandha eco-system, it has become the hour of the entomologists to concentrate on the host plant resistance, cultural practices, physical and mechanical control, organic pest control, botanicals and animal source of insecticides, biological control and biointensive modules to contain the pests problem in ashwagandha eco-system. In the present study, a biointensive module has been developed to contain key pests of ashwagandha which are to be exploited in farmers' fields through further intensification in the present line of research.

\section{CONFLICT OF INTEREST}

The authors declare that they have no conflict of interest.

\section{REFERENCES}

Balakrishnan, N., MuraliBaskaran, R. K., \& Mahadevan NR. (2005). Impact from organic manures and inorganic fertilizers on the incidence of sucking pests of cotton under rainfed condition. Madras Agricultural Journal, 92(10-12), 753-756
Balakrishnan, N., MuraliBaskaran, R. K., \& Mahadevan, N.R. (2007). Impact of manures and fertilizers on sucking pests of cotton. Annals of Plant Protection Sciences, 15(1), 235-236

Diaz Napal, G. N., Defago, M. T., Valladares, G. R., \& Palacios, S. M. (2010). Response of Epilachna paenulata to two flavonoids, pinocembrin and quercetin, in a comparative study, J. Chem. Ecol., 36, 898-904.

Kale, R. D., Bano, K., \& Satyavati, G. P. (1991). Influence of vermicompost application on growth and yield of cereals, vegetables and ornamental plant, Final Report of Karnataka State Council for Science and Technology Project, 67, 340347.

Kamrul Islam, M., Saiful, I., \& Zennat, F. (2011). Control of Epilachna vigintioctopunctata Fab. (Coleoptera: Coccinellidae) using some indigenous plant extracts, J. Life Earth Sci., 6, 75-80.

Moore, A., Watson, G., \& Bamba, J. (2014). First record of Eggplant Mealybug, Coccidohystrix insolita (Hemiptera: Pseudococcidae), on Guam: Potentially a major pest, Biodiversity Data Journal, 2, 1042

Murali Baskaran, R. K., Rajavel, D. S., Shanthi, M., Suresh, K., \& Kumar, S. (2007). Insect diversity and Damage Potential in Medicinal Plants Ecosystem, Insect Environment, 13(2), 7679

MuraliBaskaran, R. K., Senthil Kumaran, S, Rajavel, D. S., \& Suresh, K. (2009). Influence of organic source of nutrients on the management of senna pod borer, Etiella zinckenella Treit. (Lepidoptera:Phycitidae), Hexapoda, 16(1), 68-70.

Muthukrishnan, N., Ganapathy, N., Nalini, R., \& Rajendran, R. (2006). Pest Management in Horticultural Crops. Babu Offset and Colour Prints, Madurai, 373p.

Mohanchander, P., Reegan, A. D., Rahman M. A. U., \& Raveen, R. S. (2013). Effect of Hadda Beetle, Epilachna vigintioctopunctata Fab. (Coleoptera: Coccinellidae) Infestation on Eggplant Leaf (Solanum melongena L.) and Bio-control Potential of Essential Oil Formulations. Pakistan Journal of Biological Science, 16, 991-997.

Rao, K. R., Rao, P. A. \& Rao, T. K. (2001). Influence of organic manures and fertilizers on the incidence of groundnut leafminer, Aproaerema modicella Dev., Annals of Plant Protection Sciences, 9(1), 12-15

Ravikumar, A., Rajendran, R., Chinniah, C., Irulandi, S., \& Pandi, R. (2007). Evaluation of certain organic nutrient sources against mealy bug, Coccidohystrixinsolitus(Green.) and the spotted leaf beetle, Epilachnavigintioctopunctata(Fab.) on Ashwagandha, Withania somnifer, Journal of Biopesticides, 1, 28-31

Sharma, P. C., Kumar, A., Mehta, P. K. \& Singh, R. (2014). Survey studies on insect pests associated with important medicinal plants in Himachal Pradesh, Ind. J. Sci. Res. and Tech., 2(4), 2-7.

Suresh, K., Rajendran, R., \& Usha Rani, B. (2007). Eco-friendly approach for managing major sucking pests of brinjal. Journal of Entomological Research, 31(1): 19-22.

Venkatesh, D., \& David P. M. M. (2003). Efficacy of fish oil rosin soap, neem oil and insecticides against onion thrips, Thripstabaci(Lind.), Madras Agricultural Journal, 90(7-9), 562564.

Ware, G. W. (1994). The Pesticide Book. Shepard Poorman Graphics, Fresno, California, USA, 174-179. 